\title{
Notes on the Flora of the Yucatán Peninsula IX: A Reappraisal of the Genus Wimmeria (Celastraceae), Including the New Species W. lundelliana
}

\author{
Germán Carnevali Fernández-Concha, * Rodrigo Duno de Stefano, José Luis Tapia Muñoz, \\ and Ivón M. Ramírez Morillo
}

Herbarium CICY, Centro de Investigación Científica de Yucatán, A.C., Calle 43, No. 130, Col. Chuburná de Hidalgo, 97200 Mérida, Yucatán, Mexico, and A.P. 87, Cordemex, Mérida 97200, Yucatán, Mexico.*Author for correspondence: carneval@cicy.mx

ABstract. Wimmeria lundelliana Carnevali, R. Duno, J. L. Tapia \& I. Ramírez (Celastraceae) from the Yucatán Peninsula Biotic Province (YPBP) is proposed as a new species. The novelty is described, illustrated, and its affinities discussed. It appears related to $W$. obtusifolia Standley, also from the Yucatán Peninsula, which is glabrous or glabrescent overall, with proportionally broader and blunter leaves. In comparison, an amplified description and iconography of $W$. obtusifolia are offered. An epitype is designated for $W$. obtusifolia to document the fruit morphology. A taxonomic overview of Wimmeria Schlechtendal \& Chamisso in the YPBP is presented. The objectives of this paper are (1) to present a synopsis of the genus Wimmeria for the YPBP, (2) to provide a key to species identification, and (3) to describe a new species. An additional objective of this contribution is to provide an amplified description and iconography of W. obtusifolia, particularly of the fruits, which were previously undescribed.

Resumen. Se describe, ilustra y compara una nueva especie, Wimmeria lundelliana Carnevali, R. Duno, J. L. Tapia \& I. Ramírez (Celastraceae) de la porción mexicana de la Provincia Biótica Península de Yucatán (YPBP). Wimmeria lundelliana parece estar relacionada con W. obtusifolia Standley, pero es glabra o glabrescente y las hojas son más anchas y obtusas. Se incluye una descripción ampliada e iconografía de W. obtusifolia. Se designa un epitipo para $W$. obtusifolia para describir la morfología del fruto. Se presenta una sinopsis de Wimmeria Schlechtendal \& Chamisso en la YPBP. Los objetivos de este artículos son (1) presentar una sinopsis del género Wimmeria para la YPBP, (2) proporcionar una clave para la identificación de estas especies y (3) describir una nueva especie. Adicionalmente incluimos una descripción ampliada e iconografía de W. obtusifolia, con información de los frutos, los cuales hasta la fecha eran desconocidos.
Key words: Celastraceae, epitype, IUCN Red List, Mexico, Wimmeria, Yucatán Peninsula Biotic Province.

Wimmeria Schlechtendal \& Chamisso (Celastraceae) is a tree or shrub genus occurring from Mexico to Panama (Moreno, 2001). The genus is vegetatively nondescript, with simple, alternate, coriaceous leaves, often clustered at the apices of branches. Leaves are frequently produced on abbreviated branches or brachyblasts. Flowers are typically celastraceous with a well-defined, fleshy, annular disk and five stamens. The most distinctive feature of the genus is the trigonous ovary that develops into a conspicuous, 3-winged, samara-like fruit resembling a Chinese lantern.

Lundell (1939) published a treatment of the genus Wimmeria and recognized 15 species assigned to subgenus Euwimmeria Lundell, with fruits longer than wide, and subgenus Wimmeriella Lundell, with fruits broader than long. The monophyly of these sections needs to be tested in a cladistic framework because the fruit distinction is fuzzy at best and a few species are difficult to place and seem intermediate (e.g., $W$. concolor Schlechtendal \& Chamisso, W. montana Lundell, and W. obtusifolia Standley). However, for the purposes of this paper we prefer to follow Lundell's proposal since it is the only classification scheme available.

Lundell (1939) included two species for the Yucatán Peninsula Biotic Province (YPBP) area. Wimmeria bartlettii Lundell in subgenus Euwimmeria occurs from Mexico (Veracruz, Oaxaca, and Chiapas) to Panama (Chiriquí). Within the YPBP, it occurs in Petén Department in Guatemala, but has yet to be collected within Mexican territory (Lundell, 1939; Moreno, 2001). Wimmeria obtusifolia has been assigned to subgenus Wimmeriella because of its shrubby habit and pubescent leaves and twigs and is apparently endemic to the state of Yucatán (Lundell, 1939). 
Recent fieldwork within the framework of the Flora Ilustrada de la Península de Yucatán project revealed two morphologically different populations of Wimmeria in the Mexican portion of the YPBP. One of them appears to be restricted to northwestern Yucatán and is a perfect match to the type material of Standley's W. obtusifolia, a species that had apparently not been collected since Lundell's collections in the late $1930 \mathrm{~s}$. A second set of populations, occurring in more humid areas of the YPBP, which has been erroneously identified as $W$. obtusifolia by previous workers and does not match any previously described species in Wimmeria, is herein proposed as a new species, thus bringing the total number of species in YPBP to three.

Key for Wimmeria Species in the Yucatán Peninsula Biotic Province, Mexico

1a. Leaves lanceolate, lanceolate-oblong, or elliptic, $6-13.5 \times 1.8-5.5 \mathrm{~cm}$; petiole $7-12 \mathrm{~mm}$ long; inflorescence forked 2 to $4 \times$; fruits at least $1.5 \times$ longer than wide ............. bartlettii

1b. Leaves obovate to obovate-elliptic, or ellipticsuborbicular, $3-7 \times 0.9-2.8 \mathrm{~cm}$; petiole $3-$ $8 \mathrm{~mm}$ long; inflorescence 1- to 2-branched; fruits wider than long, as long as wide to less than $1.2 \times$ longer than wide. . . . . . . . . . . 2

2a. Leaves elliptic, $2-4.5 \mathrm{~cm}$ long, puberulent on both surfaces, apex obtuse or slightly rounded; fruits pale dull yellow to green-yellow with irregular reddish spots and blotches, $1-1.2 \times 1-1.7 \mathrm{~cm}$. . . . . . . . . . . . . . . Wtusifolia

2b. Leaves obovate, elliptic to elliptic-suborbicular, $3.5-7 \mathrm{~cm}$ long, glabrous on both surfaces, apex rounded, retuse, rarely narrowly obtuse; fruits concolorous, $1.2-1.4 \times 1.2-2 \mathrm{~cm} \ldots$ W. lundelliana

1. Wimmeria bartlettii Lundell, Bull. Torrey Bot. Club 65: 467. 1938, as Bartlettii. TYPE: Guatemala. Petén: Uaxactum, 2 Apr. 1931, H. H. Bartlett 12435 (holotype, A; isotypes, MICH, MO).

Distribution and ecology. This species is found in Mexico (Chiapas, Oaxaca, and Veracruz), Belize (El Cayo and Toledo), Guatemala (Petén), south into Panama. In Guatemala this plant grows in sapodilla and mahogany forests (Lundell, 1939). These forest types are also present in the southern portions of Campeche and Quintana Roo states, thus its occurrence in the Mexican portion of the YPBP is likely.

Discussion. Wimmeria bartlettii belongs in subgenus Wimmeriella with fruits longer than wide.

Selected specimens examined. BELIZE. El Cayo: Valentin, $16^{\circ} 45^{\prime} 59^{\prime \prime} \mathrm{N}, 89^{\circ} 9^{\prime} 45^{\prime \prime} \mathrm{W}$, June-July 1936, C. L. Lundell 6278 (MO). Toledo: Temash River, $16^{\circ} 0^{\prime} \mathrm{N}, 89^{\circ} 7^{\prime} \mathrm{W}, 22$ Apr. 1934 (fr.), W. A. Schipp 1296 (A, F, G, MO, NY). GUatemala. Peten: Puerto Mendez, Rolando, 17 Mar.
1970 (fl.), Tún Ortíz 776 (MO); Uaxactun, 17²3'37"N, $89^{\circ} 38^{\prime} 1^{\prime \prime} \mathrm{W}, 2$ Apr. 1931 (fl.), H. H. Bartlett 12435 (MO). MEXICO. Chiapas: Mun. Ocosingo, Nuevo Guerrero, $16^{\circ} 59^{\prime} 08^{\prime \prime} \mathrm{N}, 91^{\circ} 17^{\prime} 06^{\prime \prime} \mathrm{W}, 200 \mathrm{~m}, 11$ Apr. 2002 (fl.), G Aguilar 474 (CICY, XAL); Mun. Ocosingo a $1 \mathrm{~km}$ al S de San Javier, $16^{\circ} 47^{\prime} 22^{\prime \prime} \mathrm{N}, 91^{\circ} 06^{\prime} 06^{\prime \prime} \mathrm{W}, 295 \mathrm{~m}, 24$ ago. 2002 (fl.), C. Chancayun et al. 2140 (CICY, XAL). Veracruz: Mun. San Andres Tuxtla, faldas del Volcán San Martín, ladera S, $18^{\circ} 31^{\prime} 33^{\prime \prime} \mathrm{N}, 95^{\circ} 10^{\prime} 48^{\prime \prime} \mathrm{W}, 22$ abr. 2001 (fl., fr.), A. Rincón et al. 2331 (CICY, XAL).

2. Wimmeria Iundelliana Carnevali, R. Duno, J. L. Tapia \& I. Ramírez, sp. nov. TYPE: Mexico. Campeche: Mun. Calakmul, $31 \mathrm{~km} \mathrm{~S} \mathrm{de} \mathrm{la} \mathrm{caseta}$ de entrada a Calakmul, $18^{\circ} 17^{\prime} \mathrm{N}, 89^{\circ} 50^{\prime} 6^{\prime \prime} \mathrm{W}$, $180 \mathrm{~m}$, selva mediana subcaducifolia, árbol $10 \mathrm{~m}$ con flor blanca, 24 Nov. 1997, E. Martínez, D. Álvarez, S. Ramírez, E. Lira \& E. Madrid 29902 (holotype, CICY; isotypes, MEXU, MO). Figure 1.

Species haec Wimmeriae obtusifoliae Standley similis, sed ab ea foliis glaberrimis (vs. puberulis) latioribus apice rotundato vel emarginato, petiolis laxe pilosis (vs. puberulis) atque fructibus concoloribus majoribus differt.

Tree 10-20 m high; young branches minutely and sparsely pilose. Leaves borne mainly at the apex of short branches, alternate, simple, coriaceous, drying light brown on both surfaces, slightly paler abaxially; stipules minute, caducous. Petioles 4-8 mm, shallowly canaliculate, sparse and minutely pilose; leaves subcoriaceous, blades obovate to elliptic, elliptic, or ellipticsuborbicular, 3.5-7 $\times 0.9-2.8 \mathrm{~mm}$, apex rounded, retuse, or rarely narrowly obtuse, base attenuate, glabrous on both surfaces, nervation penninerved, central nerve prominent abaxially, inconspicuous adaxially, secondary nerves arising at $45^{\circ}-60^{\circ}$ to central nerve at first, then curving distally, not reaching the margins or the apex, margin crenate, subcrenate to almost entire. Inflorescences usually 7 -flowered cymes, sometimes reduced to 1 flower, $1.5-2.5 \mathrm{~cm}$, peduncle 9-12 mm, minutely pilose, first-order branches ca. $2 \mathrm{~mm}$, second-order branches 1-flowered, ca. $2 \mathrm{~mm}$, pedicel 4-5 mm, floral bracts ca. $1 \mathrm{~mm}$, narrowly triangular, concave, sparsely and minutely pilose. Flowers perfect, actinomorphic, bisexual; calyx 5lobed, lobes subequal, transversely oblong, apex broadly rounded, $0.3-0.5 \times 1.5-2 \mathrm{~mm}$, glabrous on both surfaces; corollas pentamerous, imbricate, petals ovate, $3-3.5 \times$ ca. $2 \mathrm{~mm}$, apex obtuse, glabrous on both surfaces; stamens 5, inserted on margin of disk, ca. $2.5 \mathrm{~mm}$, alternate to petals, filaments filiform, ca. $2 \mathrm{~mm}$, glabrous, anthers basifixed, sagittate, 2-celled, longitudinally dehiscent; disk conspicuous, 5-lobate, surrounding the ovary, fleshy; ovary 2 - to 3 -keeled, 3 celled, base submerged in disc, ca. $1.5 \mathrm{~mm}$ high, style ca. $1 \mathrm{~mm}$ long, glabrous, stigma capitate, sometimes 2 - 


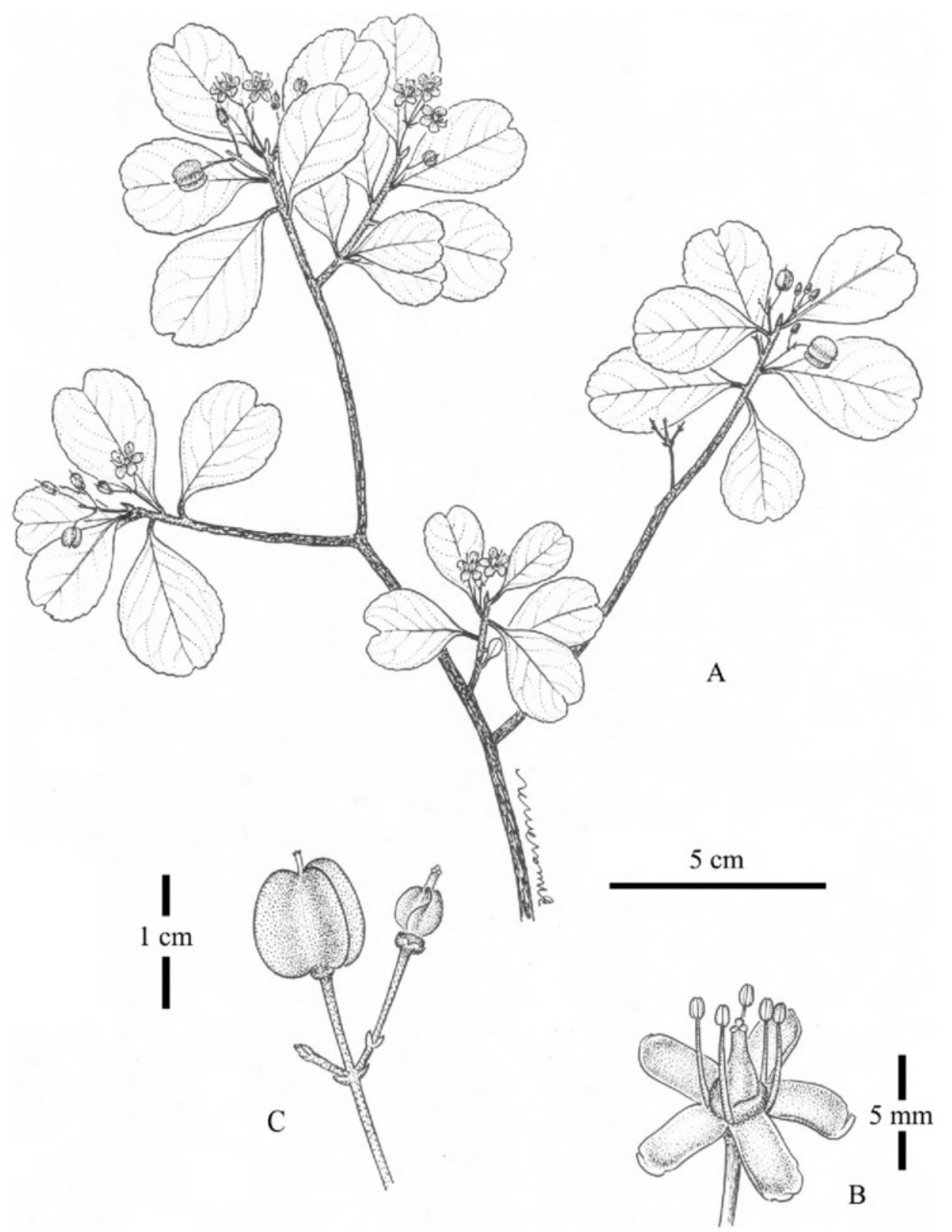

Figure 1. Wimmeria lundelliana Carnevali, R. Duno, J. L. Tapia \& I. Ramírez. -A. Habit with inflorescence and infrutescence branches. - B. Detail of flower. - C. Detail of fruit. Drawn from E. Martínez, D. Álvarez, S. Ramúrez, E. Lira \& E. Madrid 29902 (CICY).

to 3-fid. Fruits 3(rarely 2)-winged, depressed-orbicular, $1.2-1.4 \times 1.2-2 \mathrm{~cm}$, concolorous, notched at apex and base, crowned at apex by the persistent stigma and style, glabrous, indehiscent; wings membranous, with numerous fine, closely set, nearly parallel veins almost perpendicular to fruit axis.

Distribution and ecology. The new species is endemic to the Yucatán Peninsula in Mexico, only known from the south-central and eastern portions of Campeche and Quintana Roo states. It grows in subcaducifolious medium-statured forests with an annual precipitation of 1100-1400 mm (Carnevali et al., 2003).

\section{IUCN Red List category. Wimmeria lundelliama} can be classified as Endangered (EN) according to IUCN Red List criteria Bla,b (IUCN, 2001). It has only been collected in two localities, which are ca. 
$350 \mathrm{~km}$ distant from each other. One of these localities resides within the Calakmul Biosphere Reserve, where it is legally protected. The second known locality, however, is along the Cancún-Tulúm road, where touristic development is a major threat.

Etymology. The species epithet honors Cyrus Longworth Lundell (1907-1994), a prolific botanist who spent much of his career working in Central America, including the Yucatan Peninsula.

Discussion. Wimmeria lundelliana belongs to subgenus Wimmeriella because of its fruits that are wider than long. There are four species of Wimmeria in southeastern Mexico that form a natural alliance, referred to as section Trichocarpae by Radlkofer in 1878 (cited by Lundell, 1939: 9): W. microphylla Radlkofer, W. pubescens Radlkofer, W. obtusifolia, and W. cyclocarpa Radlkofer. Wimmeria lundelliana seems to belong in this alliance, although it is unusual in featuring glabrous fruits and leaves. The new species resembles $W$. obtusifolia but differs in the leaves that are longer (3.5-7 mm vs. 2-4.5 mm), usually obovate with apex rounded to emarginate (vs. elliptic with apex obtuse), and glabrous (vs. puberulent on both surfaces), and in the fruits that are $1.2-1.4 \times 1.2-2 \mathrm{~cm}$ (vs. $1-1.2$ $\times 1-1.7 \mathrm{~cm})$. The new species resembles W. acapulcensis Lundell (from another alliance, Leiocarpae Radlkofer, with four species from western Mexico), but the leaves of the western Mexican species have longer petioles (5-15 mm vs. 4-8 mm) and the leaves are narrower (narrowly ovate to ovate vs. generally obovate, elliptic, or elliptic-suborbicular).

Paratypes. MEXICO. Campeche: Mun. Calakmul, $31 \mathrm{~km}$ al S de la caseta de entrada a Calakmul, $18^{\circ} 17^{\prime} 12^{\prime \prime} \mathrm{N}, 89^{\circ} 50^{\prime} 11^{\prime \prime} \mathrm{W}, 145 \mathrm{~m}$, mediana subcaducifolia, 19 oct. 1997 (fl.), E. Martínez, D. Álvarez, S. Ramúrez, E. Lira y E. Madrid 29121 (CICY, MEXU, MO); same locality, 19 oct. 1997 (fl.), E. Martínez, D. Álvarez, S. Ramúrez, E. Lira y E. Madrid 29121a (CICY); same locality, 19 oct. 1997 (fl.), E. Martínez, D. Álvarez, S. Ramírez, E. Lira y E. Madrid 29123 (CICY); same locality, 24 nov. 1997 (fr.), E. Martínez, D. Álvarez y S. Ramírez 29888 (CICY, MEXU, MO); same locality, 24 nov. 1997 (fl.), E. Martínez, D. Álvarez y S. Ramúrez 29902 (CICY, MEXU, MO). Quintana Roo: Mun. Solidaridad, $7 \mathrm{~km}$ sur de Akumal, carr. Cancún-Tulúm, $20^{\circ} 23^{\prime} 47^{\prime \prime} \mathrm{N}, 87^{\circ} 18^{\prime} 49^{\prime \prime} \mathrm{W}, 17$ dic. 1982 (fr.), E. Cabrera \& H. de Cabrera 3984 (MEXU, MO).

3. Wimmeria obtusifolia Standley, Field Mus. Bot. 8: 20. 1930. TYPE: Mexico. Yucatán: s. loc., 1917, G. F. Gaumer 24259 (holotype, F; isotypes, A, M, MO, NY, US). EPITYPE: Mexico. Yucatán: Mun. Tetiz, Tetiz, $20^{\circ} 57^{\prime} 41^{\prime \prime} \mathrm{N}, 89^{\circ} 56^{\prime} 09^{\prime \prime} \mathrm{W}$, 15 m, 20 Oct. 2006 (fl., fr.), G. Carnevali 7185 (epitype, designated here, CICY; duplicates, MEXU, MO, NY). Figure 2.
Trees to $15 \mathrm{~m}$ high; young branches whitish, puberulent, older branches often lenticellate. Leaves small, slightly discolorous, chartaceous, brittle; petioles puberulent, 3-6 mm; blades elliptic, 2-4.5 × 1-2.5 cm, apex obtuse, sometimes slightly rounded, base acute, attenuate, margin subentire, inconspicuously crenate, sparsely puberulent on both surfaces, middle nerve distinct on adaxial surface, less distinct abaxially. Inflorescences cymose, to $2 \mathrm{~cm}$, puberulent, lax, 3- to 7-flowered, 1.5$2 \mathrm{~cm}$, peduncle $7-9 \mathrm{~mm}$, minutely pilose, first-order branches ca. 0.5-1.5 mm, second-order branches 1flowered, ca. $2 \mathrm{~mm}$, pedicel 4-7 mm, floral bracts ca. $1 \mathrm{~mm}$, triangular, concave, sparsely and minutely pilose. Flowers white, bracts and bracteoles inconspicuous; calyx 5-lobed, the lobes equal, rounded, 1-2.5 × 1$2.5 \mathrm{~mm}$, apex obtuse, puberulent; corollas pentamerous, imbricate, petals obovate to suborbicular, $3-4 \times$ ca. $2 \mathrm{~mm}$; stamens 5 , inserted on margin of disk, 3-4 mm, altemate to petals; filaments $2-3 \mathrm{~mm}$, anthers ca. $1 \mathrm{~mm}$, disc black-punctate. Ovary 3-keeled, 3-celled, base embedded in the disc, ca. $1.5 \mathrm{~mm}$ long, style ca. $1.5 \mathrm{~mm}$, glabrous, stigma 3 -fid. Fruits sparsely puberulent, 3-winged, 1-1.2 × 1-1.7 cm, pale dull yellow to green-yellow with irregular reddish spots and blotches.

Distribution and ecology. Wimmeria obtusifolia is endemic to the Yucatán Peninsula and is known only from northern Yucatán and Quintana Roo states in Mexico. The species grows in low deciduous forest with an annual precipitation of 500-600 mm, ranging eastward into subcaducifolious medium-statured forests with an annual precipitation of $1100-1200 \mathrm{~mm}$ (Carnevali et al., 2003).

IUCN Red List category. Wimmeria obtusifolia can be classified as Endangered (EN) according to IUCN Red List criteria Bla,b (IUCN, 2001). It has been collected in three localities on a narrow belt of ca. $300 \mathrm{~km}$ along the central zone of Yucatán and northem Quintana Roo states. These localities are affected by high anthropogenic impact due to touristic developments (Quintana Roo) and by land-use changes resulting from agriculture and cattle ranching.

Discussion. Wimmeria obtusifolia was described by Standley (1930) in his Flora of Yucatan, from a collection of G. F. Gaumer (24259, MO) made between 1917 and 1921 from northern Yucatán. Wimmeria obtusifolia was referred by Lundell (1939) to subgenus Wimmeriella, despite the fact that fruiting material was unavailable. Because classifications of Wimmeria, at both the sectional and subgeneric levels, are essentially based on fruit characteristics, we propose an epitype above. The shape of the fruits collected recently supports the referral of W. obtusifolia to subgenus Wimmeriella. Some relevant litera- 


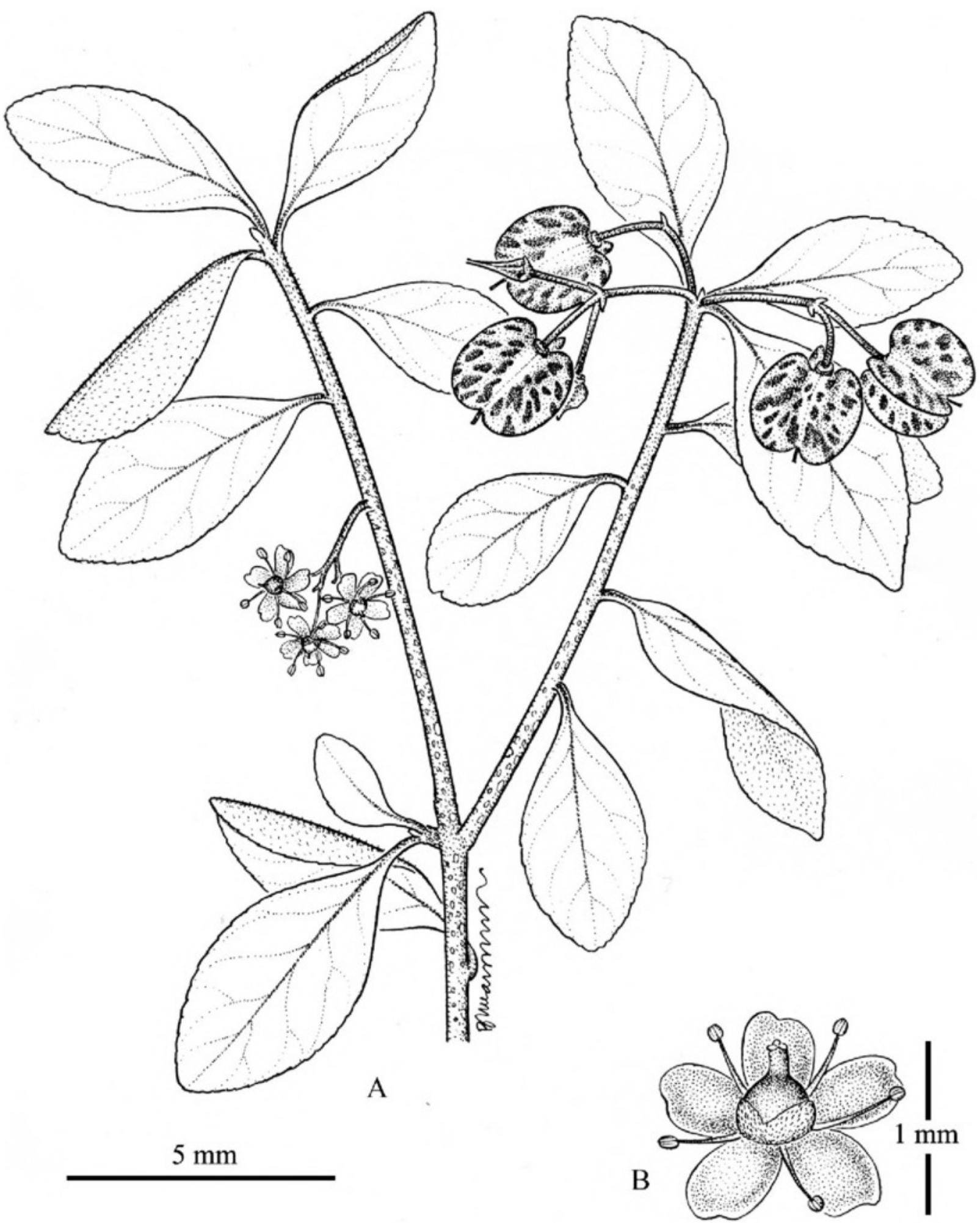

Figure 2. Wimmeria obtusifolia Standley -A. Habit with inflorescence and infrutescence branches. -B. Detail of flowers. Drawn from the epitype G. Carnevali 7185 (CICY).

ture for the YPBP area treats the collections from Calakmul as W. obtusifolia (Durán et al., 2000; Martínez et al., 2001), but these collections are better referable to the new species, $W$. lundelliana.

Selected specimens examined. MEXICO. Quintana Roo: Mun. Solidaridad, $8 \mathrm{~km} \mathrm{~S}$ de Puerto Morelos, carr.
Cancún-Chetumal, $20^{\circ} 47^{\prime} 50^{\prime \prime} \mathrm{N}, 86^{\circ} 56^{\prime} 25^{\prime \prime} \mathrm{W}, 0 \mathrm{~m}$ s.m., 22 ene. 1989 (fl.), I. Olmsted 290 (CICY). Yucatán: Mun. Tetiz, Nohuayún, a $800 \mathrm{~m}$ de la Escuela Secundaria de Nohuayún, $20^{\circ} 57^{\prime} 41^{\prime \prime} \mathrm{N}, 89^{\circ} 56^{\prime} 09^{\prime \prime} \mathrm{W}, 15 \mathrm{~m}$, 20 oct. 2006 (fl., fr.), L María Calvo s.n. (CICY, MEXU, MO); Mun. Chicxulub, entre Chicxulub Puerto y Chicxulub Pueblo, $21^{\circ} 14^{\prime} 8.61^{\prime \prime} \mathrm{N}, 89^{\circ} 31^{\prime} 58.13^{\prime \prime} \mathrm{W}, 5-8 \mathrm{~m}$, 13 nov. 2008, G. Carnevali, R. Duno, J. C. Trejo \& D. 
Angulo 7400 (BRIT, CICY, HUH, MEXU, MO, SEL, TEX, UCAM).

Acknowledgments. We thank Bruno Manara for the line drawings of Wimmeria lundelliana and $W$. obtusifolia. Luz María Calvo (CICY) prompted our interest in this genus after providing us with an excellent collection of Wimmeria, which proved to be the rediscovery of $W$. obtusifolia. Jorge Carlos Trejo Torres, of Ciudadanos del Karso, carefully read an earlier draft of the manuscript.

\section{Literature Cited}

Carnevali, G., I. Ramírez-Morillo \& J. A. González-Iturbe. 2003. Flora y vegetación de la Península de Yucatán. Pp. 53-68 en P. Colunga García-Marín \& A. Larqué Saavedra (editores), Naturaleza y Sociedad del Área Maya: Pasado, Presente y Futuro. Centro de Investigación Científica de Yucatán, A.C. Mérida, Yucatán.
Durán, R., G. Campos, J. C. Trejo, P. Simá, F. May Pat \& M. Juan Qui. 2000. Listado Florístico de la Península de Yucatán. Centro de Investigación Científica de Yucatán, A.C., Mérida, Yucatán.

IUCN. 2001. IUCN Red List Categories and Criteria, Version 3.1. Prepared by the IUCN Species Survival Commission. IUCN, Gland, Switzerland, and Cambridge, United Kingdom.

Lundell, C. L. 1939. Revision of the American Celastraceae I. Wimmeria, Microtropis, and Zinowiewia Contr. Univ. Michigan Herb. 3: 6-46.

Martínez, E., M. Sousa S. \& C. H. Ramos Álvarez. 2001. Listados Florístico de México. XXII. Región de Calakmul, Campeche. Universidad Nacional Autónoma de México, México, D.F.

Moreno, P. P. 2001. Celastraceae. Pp. 596-601 in W. D. Stevens, C. Ulloa Ulloa, A. Pool \& O. M. Montiel (editors), Flora de Nicaragua, Tomo I: Introducción, Gimnospermas y Angiospermas (Acanthaceae-Euphorbiaceae). Monogr. Syst. Bot. Missouri Bot. Gard. 85.

Standley, P. C. 1930. Flora of Yucatan. Field Mus. Nat. His., Bot. Ser. 3(3): 157-492. 


\section{$2 \mathrm{BHL}$ Biodiversity Heritage Library}

Carnevali Fernández-Concha, Germán et al. 2009. "Notes on the Flora of the Yucatán Peninsula IX: A Reappraisal of the Genus Wimmeria (Celastraceae), Including the New Species W. lundelliana." Novon a journal of botanical nomenclature from the Missouri Botanical Garden 19, 150-155.

View This Item Online: https://www.biodiversitylibrary.org/item/124658

Permalink: https://www.biodiversitylibrary.org/partpdf/121893

\section{Holding Institution}

Missouri Botanical Garden, Peter H. Raven Library

\section{Sponsored by}

Missouri Botanical Garden

\section{Copyright \& Reuse}

Copyright Status: Permission to digitize granted by rights holder Rights: https://www.biodiversitylibrary.org/permissions

This document was created from content at the Biodiversity Heritage Library, the world's largest open access digital library for biodiversity literature and archives. Visit BHL at https://www.biodiversitylibrary.org. 